\title{
APLIKASI PENGOLAHAN DATA KEUANGAN BERBASIS JAVA PADA CV. ADM TECHNOLOGY MENGGUNAKAN NETBEANS
}

\author{
Rachmadi Rama \\ Universitas Indraprasta PGRI \\ Jl. Raya Tengah No. 80 Kelurahan Gedong, Kecamatan Pasar Rebo, Jakarta Timur 13760 \\ rachmadislamdunk@gmail.com
}

\begin{abstract}
ABSTRAK
Keuangan merupakan bagian yang penting dalam sebuah perusahaan, dimana sebuah perusahaan harus mengetahui pemasukan dan pengeluaran untuk mengetahui keuntungan dan kerugian yang didapat. Persediaan keuangan yang belum terkendali, sehingga banyak terjadi hal diluar dugaan yang dapat merugikan. Kata kunci dari masalahnya adalah pengolahan data keuangan. Tujuan peneliti adalah untuk membantu user dalam mengelola keuangan untuk meminimalisir kesalahan perhitungan dan pelaporan keuangan kepada atasan dengan membuatkan aplikasi untuk mengelola data keuangan. Metodologi yang di gunakan adalah metode waterfall dan menggunakan metode UML. Dengan bahasa program JAVA, MySQL untuk mengelola database, NetBeans sebagai code editor. Hasil yang didapat peneliti adalah aplikasi ini dapat menangani halhal yang dibutuhkan perusahaan selama melakukan pengolahan data keuangan diantaranya terdapat fitur keuangan masuk dan keluar untuk mengetahui sirkulasi keuangan, fitur laporan untuk mengevaluasi keuangan perusahaan.
\end{abstract}

Kata Kunci: Aplikasi Keuangan, Pengolahan Data, Keuangan.

\begin{abstract}
Finance is an essential part of a company, where a company must know the income and expenses to find out the profits and losses obtained. Financial inventory is not control so that many unexpected things happen that can be detrimental. The keyword of the problem is financial data processing. The researcher aims to assist users in managing finances to minimize miscalculations and financial reporting to superiors by developing applications to manage financial data. The methodology used is the waterfall method and uses the UML method. With JAVA programming language, MySQL for managing databases, NetBeans as a code editor. The results obtained by the researcher are that this application can handle things that are needed by the company while processing financial data, including there are incoming and outgoing financial features to determine financial circulation, report features to evaluate company finances.
\end{abstract}

Key Word: Financial Applications, Data Processing, Finance.

\section{PENDAHULUAN}

Keuangan merupakan bagian yang penting dalam sebuah perusahaan, di mana sebuah perusahaan harus mengetahui pemasukan dan pengeluaran untuk mengetahui keuntungan dan kerugian yang didapat. Sudah selayaknya bila perusahaan sangat memperhatikan keuangan yang dapat merekam jejak kerugian dan keuntungan sehingga dapat menekan kecurangan dalam penggunaan dana perusahaan.

Seringkali dalam perusahaan terjadi kelebihan pengeluaran dana yang tidak pasti, kelebihan dana merupakan suatu pemborosan karena terjadi investasi yang berlebihan. Persediaan keuangan CV. ADM Technology belum terkendali, sehingga banyak terjadi hal diluar dugaan yang dapat merugikan. Pada saat tertentu keuntungan perusahaan sangat besar, sehingga tidak memikirkan total pengeluaran yang dikeluarkan sebanding atau tidak dari total pemasukan.

Dalam persetujuan pengajuan dana memerlukan waktu yang lama untuk disetujui oleh atasan sehingga dapat berdampak pada lamanya perusahaan dalam meng-handle proyek yang dapat berdampak juga pada kepercayaan customer dalam kerja sama suatu proyek. Dengan demikian pengolahan data keuangan yang dapat merekam pengeluaran, pemasukan, penggajian karyawan dan kebutuhan internal perusahaan sangatlah penting. 
"Aplikasi bisa dikatakan suatu perangkat lunak yang siap pakai dengan menjalankan instruksi dari pengguna (user), aplikasi banyak diciptakan untuk membantu berbagai keperluan, seperti contoh: membuat laporan, percetakan dan lain-lain"'(Dosen Pendidikan, 2014).

"pengolahan data adalah manipulasi data menjadi bentuk sebuah informatif. Informasi adalah hasil dari pemrosesan data dalam bentuk tertentu yang lebih bermakna daripada suatu kegiatan atau peristiwa"(Pelayanan Publik, 2020).

"Keuangan mempelajari bagaimana cara mengetahui berbisnis individu, meningkatkan organisasi, mengalokasi, menggunakan sumber daya moneter dengan sejalannya waktu, dan juga menghitung risiko dalam menjalankan proyeknya."(Rynny, 2019).

"Java adalah sebuah teknologi yang diperkenalkan oleh Sun Microsysytems pada pertengahan tahun 1990. Menurut definisi Sun, Java adalah nama untuk sekumpulan teknologi untuk membuat dan menjalankan perangkat lunak pada computer standalone ataupun pada lingkungan jaringan"(Darmansyah, 2014).

"NetBeans adalah Integrated Development Environment (IDE) berbasiskan Java dari Sun Microsystems yang berjalan diatas Swing. Swing sebuah teknologi Java untuk pengembangan aplikasi Desktop yang dapat berjalan diberbagai macam platforms seperti Windows, Linux, MacOSX and Solaris"(Zahra et al., 2018).

"MySQL adalah salah satu aplikasi DBMS (Database Management System) yang sudah sangat banyak digunakan oleh para pemrogram aplikasi web. Dalam sistem database tak relasional, semua informasi disimpan pada satu bidang luas, yang kadangkala data didalamnya sangat sulit dan melelahkan untuk diakses. Tetapi MySQL merupakan sebuah sistem database relasional, sehingga dapat mengelompokkan informasi ke dalam tabel-tabel atau grup-grup informasi yang berkaitan.

Setiap tabel memuat bidang-bidang yang terpisah, yang mempresentasikan setiap bit informasi. MySQL menggunakan indeks untuk mempercepat proses pencarian terhadap baris informasi tertentu. MySQL memerlukan sedikitnya satu indeks pada tiap tabel. Biasanya akan menggunakan suatu primary key atau pengenal unik untuk membantu penjejakan data"(Sianipar, 2015).

\section{METODE PENELITIAN}

Metode penelitian yang digunakan penulis adalah metode penelitian grounded research, "grounded research adalah suatu metode penelitian yang mendasarkan pada fakta dan menggunakan analisis perbandingan dengan bertujuan untuk mengadakan generalisasi empiris, menetapkan konsep-konsep, membuktikan teori, dan mengembangkan teori yang dilakukan peneliti secara bersamaan antara pengumpulan data dengan analisis data"(Santosa, 2015).

Penulis mencari informasi dan mengumpulkan data dari perusahaan, penulis juga melakukan klasifikasi pada data tersebut, bagaimana sistem mengolah data, menyimpan data serta menulis hasil laporan. Dengan pengumpulan data menggunakan beberapa cara:

- Mencari berbagai referensi yang berkaitan dengan Pemrograman Java.

- Melakukan pengamatan langsung terhadap pengolahan data keuangan CV. ADM Technology

- Wawancara dilakukan ke bagian keuangan sebagai penanggung jawab pengolahan data keuangan CV. ADM Technology

Adapun metode pengembangan aplikasi pengolahan data keuangan berbasis java pada CV. ADM Technology menggunakan NetBeans, penulis menggunakan pemodelan waterfall. Pada proses waterfall ditunjukkan metode pengembangan di mana pengembang aplikasi diharuskan mengikuti langkahlangkah sebagai berikut: 


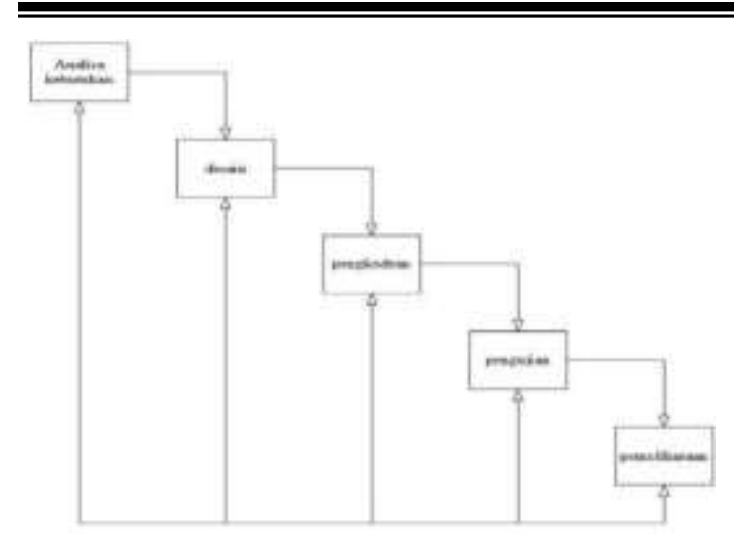

Gambar 1. Metode Waterfall

Sumber : Ajid \& Rismayadi (2021)

\section{HASIL DAN PEMBAHASAN}

Hasil analisa dari penelitian ini ditemukan masalah pada saat setelah transaksi dilakukan, user akan mencatat data dengan cara manual dan tulis tangan, kemudian data tersebut diarsipkan dalam suatu dokumen yang mengakibatkan data tidak aman dan sering terjadi perhitungan. Dalam pembuatan sebuah laporan keuangan membutuhkan waktu lama yang mana data harus disalin kembali secara manual, sehingga dalam pembuatan sebuah laporan menjadi tidak efektif dan efisien. Maka, perlu ada aplikasi yang menyelesaikan perhitungan keuangan dan yang dapat mengamankan data yang dapat diakses dengan cepat untuk melihat laporan keuangan. Kerangka berpikir dibuat untuk penjelasan sementara terhadap suatu gejala yang menjadi objek permasalahan, berikut kerangka berpikir yang dibuat:

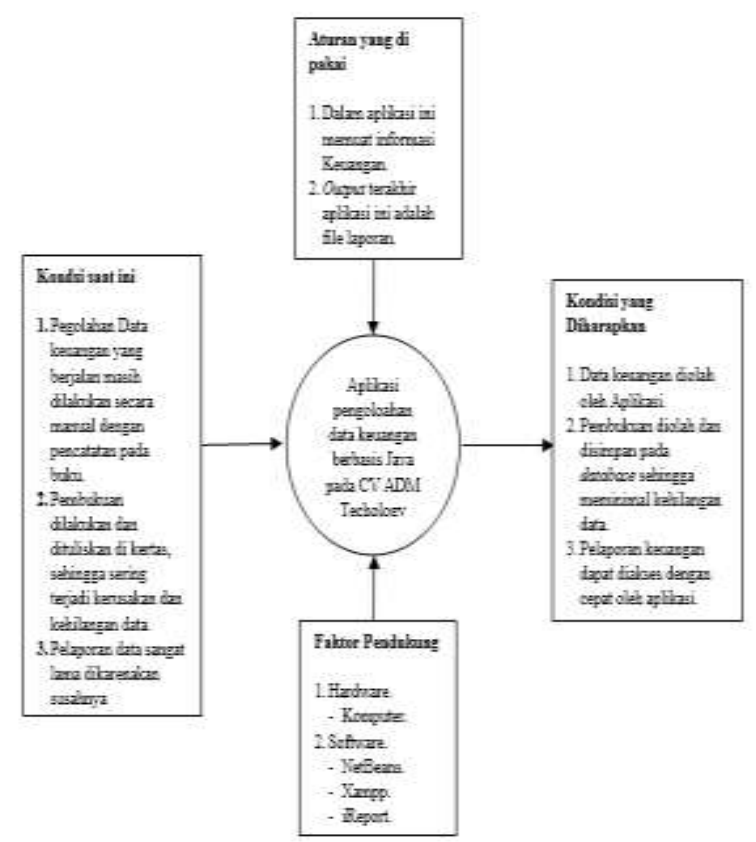

Gambar 2. Kerangka Berpikir
Dilihat dari gambar kerangka berpikir diatas, maka keterangan dari gambar tersebut diatas adalah sebagai berikut :

1. Bagan pertama, kondisi saat ini pada pengolahan keuangan CV. ADM Technology.

2. Bagan kedua, mengenai aturan- aturan yang dipakai.

3. Bagan ketiga, dengan terciptanya suatu aplikasi ini dibutuhkan faktor- faktor pendukung.

4. Bagan keempat, kondisi yang diharapkan oleh user.

Dekomposisi fungsi sistem di rancang untuk menyelesaikan aplikasi pengolahan data keuangan adalah sebagai berikut:

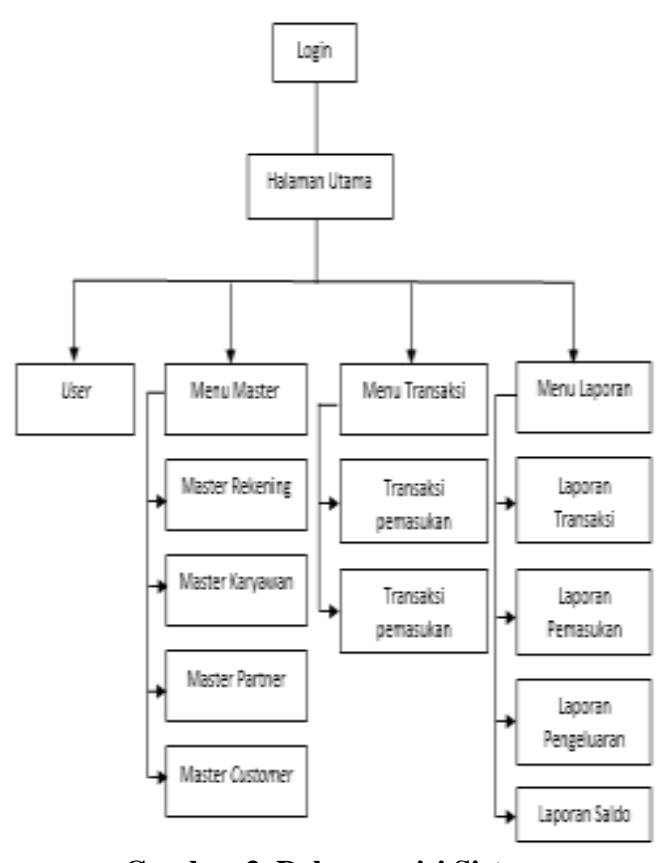

Gambar 3. Dekomposisi Sistem

"Use case diagram menjelaskan manfaat sistem jika dilihat menurut pandangan orang yang berada diluar sistem atau actor. Diagram ini menunjukkan fungsionalitas suatu sistem atau kelas dari bagaimana sistem berinteraksi dengan dunia luar"(Fitriani et al., 2018). Berikut adalah gambar proses use case diagram dari sistem: 


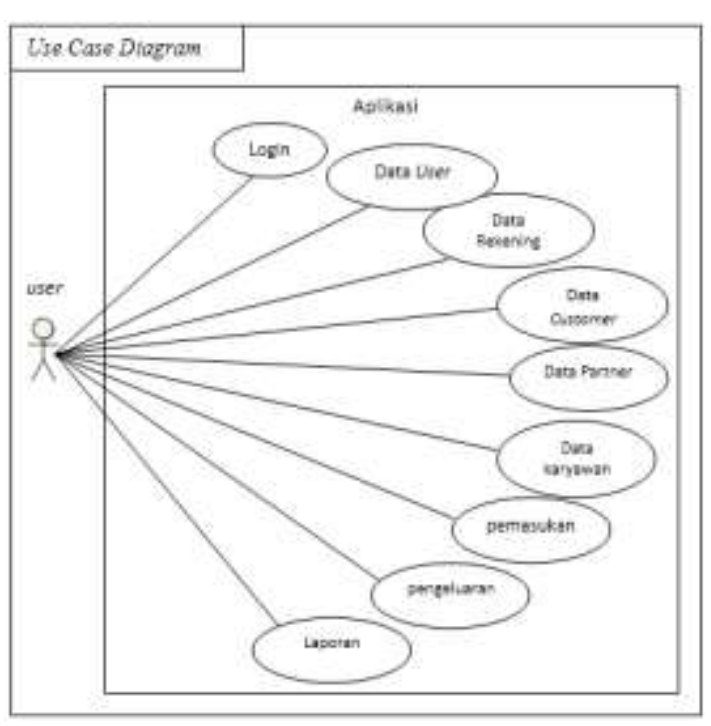

Gambar 4. Use Case Diagram

Dalam Use Case Diagram diatas user mempunyai hak penuh dalam mengakses aplikasi pengolahan keuangan, yang berperan sebagai user adalah staf keuangan.

"ERD menggambarkan entity-relationship model yang merupakan gabungan konsep entitas, atribut, dan hubungan antar entitas, dan entitas dalam ERD merepresentasikan sesuatu (things) atau benda dalam dunia nyata"(Adi \& Kristin, 2014).

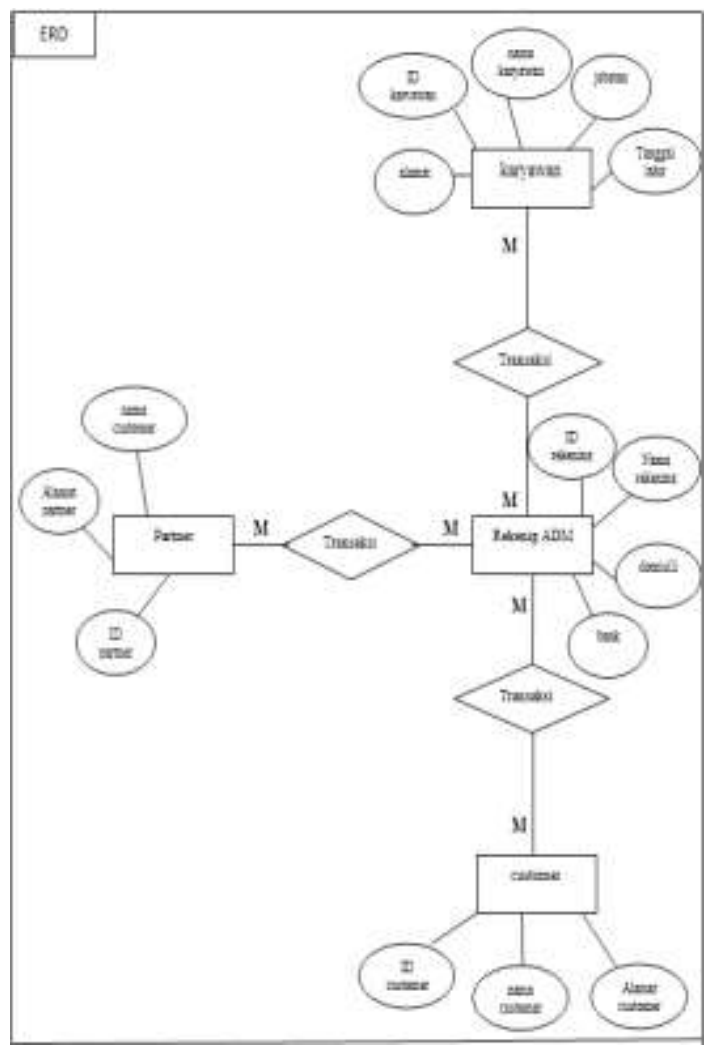

Gambar 5. ERD
Tampilan Layar Aplikasi

Form Login

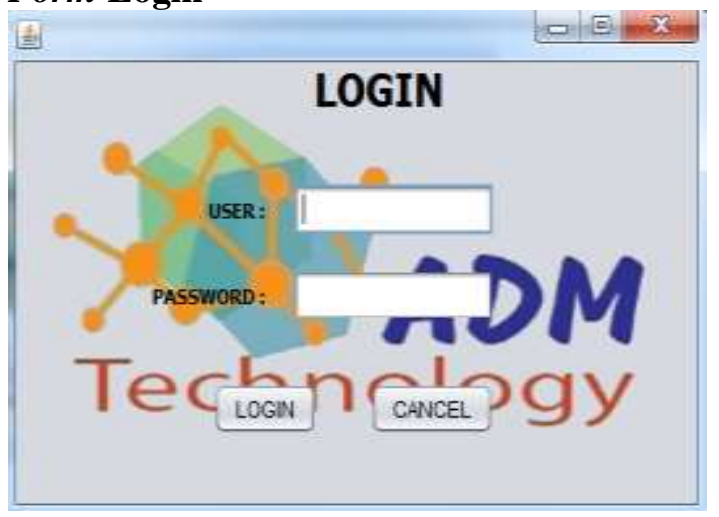

Gambar 6. Form Login

Menu login digunakan sebagai kata kunci sebelum memasuki program utama, agar tidak sembarang orang dapat mengakses program ini. Sehingga dalam form menu kerahasiaannya dapat terjaga dengan baik.

\section{Form Menu Utama}

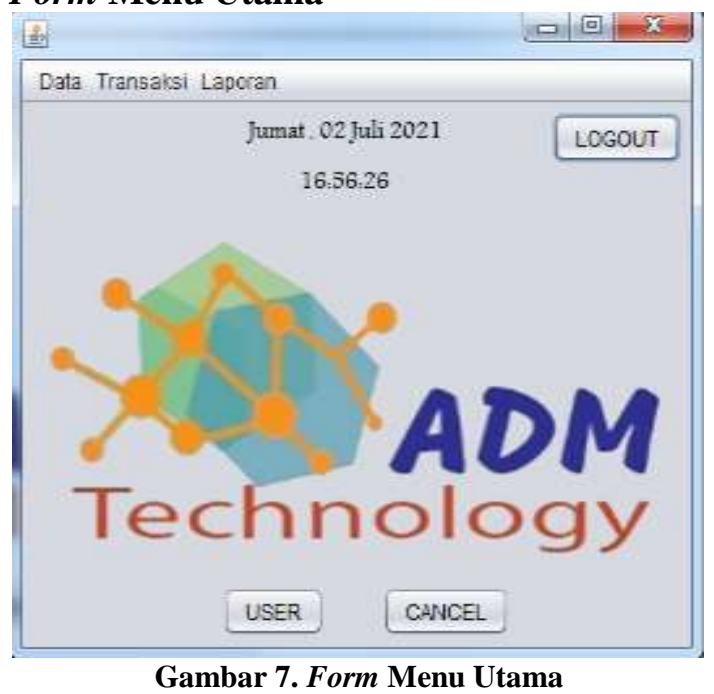

Pada layar utama terdapat menu bar yang terdiri dari menu data, transaksi, dan laporan. Pada menu utama ini juga memiliki beberapa tombol yaitu tombol user untuk ke form user, tombol cancel untuk keluar program tombol logout untuk kembali ke form login. 


\section{Form User}

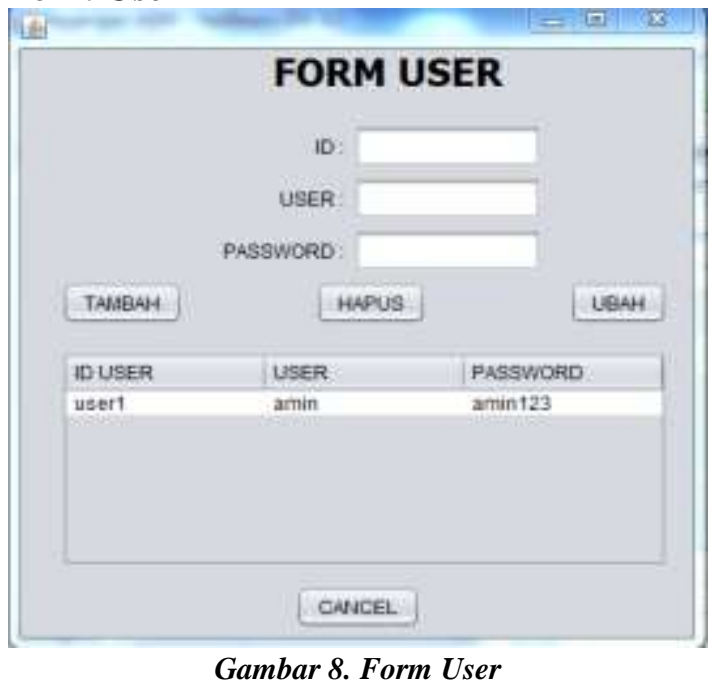

Form ini memiliki beberapa fungsi tombol yang terdiri dari tombol tambah untuk menambahkan data yang telah di-input user, sedangkan tombol ubah digunakan untuk mengubah data yang telah di-input user, tombol hapus berfungsi ketika user ingin menghapus data. serta tombol cancel digunakan untuk kembali ke menu utama.

\section{Form Karyawan}

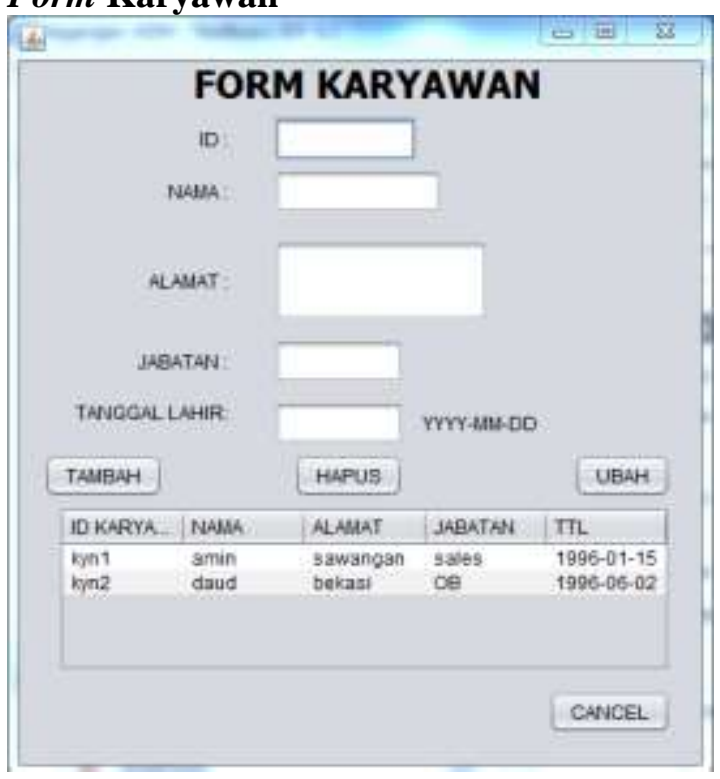

Gambar 9. Form Karyawan

Form ini memiliki beberapa fungsi tombol yang terdiri dari tombol tambah untuk menambahkan data yang telah di-input user, sedangkan tombol ubah digunakan untuk mengubah data yang telah di-input user, tombol hapus berfungsi ketika user ingin menghapus data. serta tombol cancel digunakan untuk kembali ke menu utama.

\section{Form Customer}

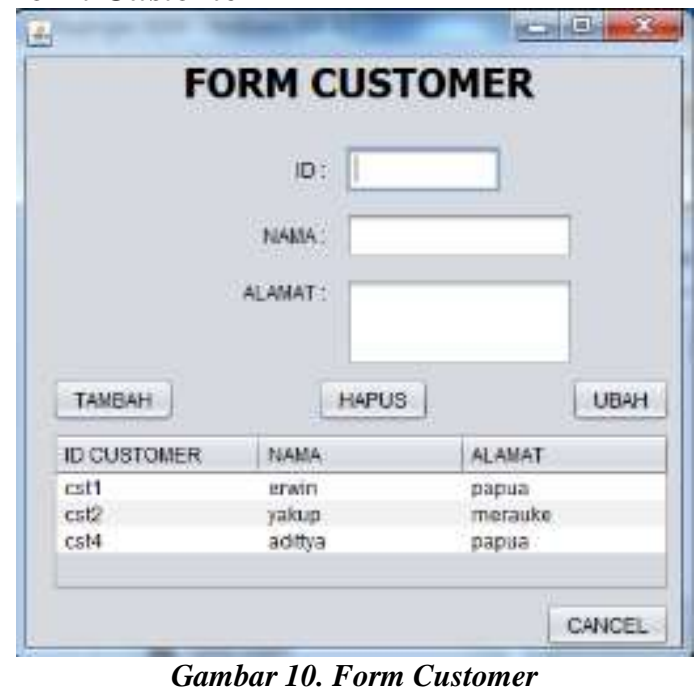

Form ini memiliki beberapa fungsi tombol yang terdiri dari tombol tambah untuk menambahkan data yang telah di-input user, sedangkan tombol ubah digunakan untuk mengubah data yang telah di-input user, tombol hapus berfungsi ketika user ingin menghapus data. serta tombol cancel digunakan untuk kembali ke menu utama.

\section{Form Partner}

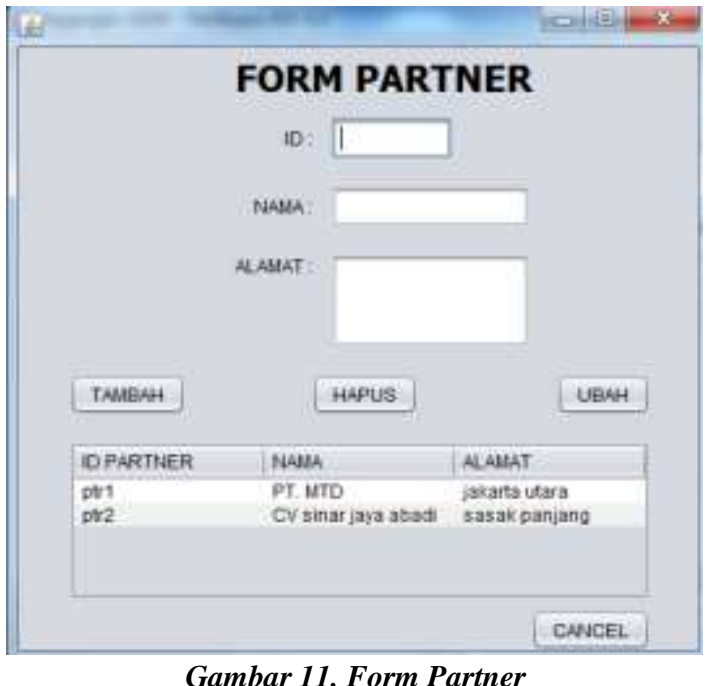

Form ini memiliki beberapa fungsi tombol yang terdiri dari tombol tambah untuk menambahkan data yang telah di-input user, sedangkan tombol ubah digunakan untuk mengubah data yang telah di-input user, tombol hapus berfungsi ketika user ingin menghapus data. serta tombol cancel digunakan untuk kembali ke menu utama. 


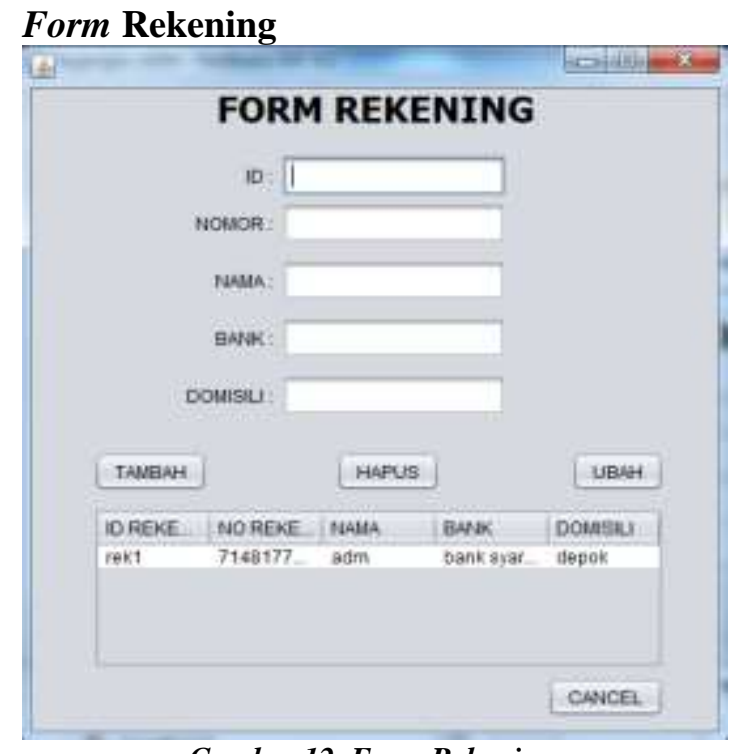

Gambar 12. Form Rekening

Form ini memiliki beberapa fungsi tombol yang terdiri dari tombol tambah untuk menambahkan data yang telah di-input user, sedangkan tombol ubah digunakan untuk mengubah data yang telah di-input user, tombol hapus berfungsi ketika user ingin menghapus data. serta tombol cancel digunakan untuk kembali ke menu utama.

\section{Form Pemasukan}

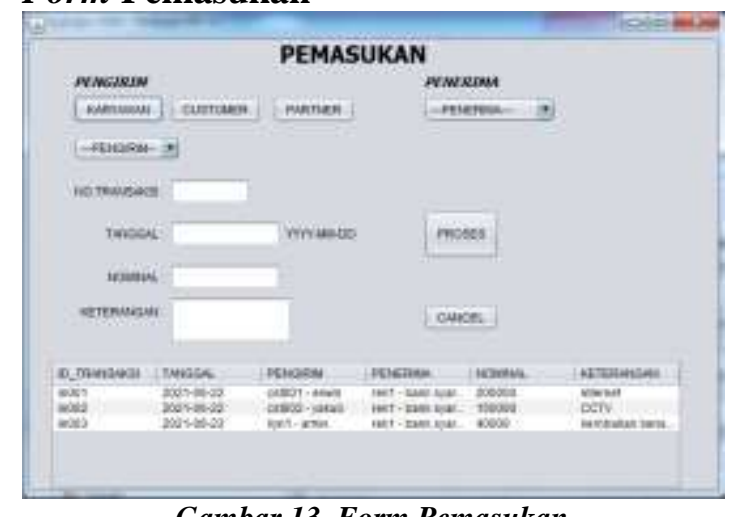

Gambar 13. Form Pemasukan

Form ini memiliki beberapa fungsi tombol yang terdiri dari pilihan tombol pengirim yang terdiri dari tombol (karyawan, customer, partner) yang berfungsi untuk memilih sumber pengirim, lalu terdapat combobox untuk memilih pengirim dan penerima keuangan, tombol proses digunakan untuk menambah data yang telah di-input user, serta tombol cancel digunakan untuk kembali ke menu utama.

\section{Form Pengeluaran}

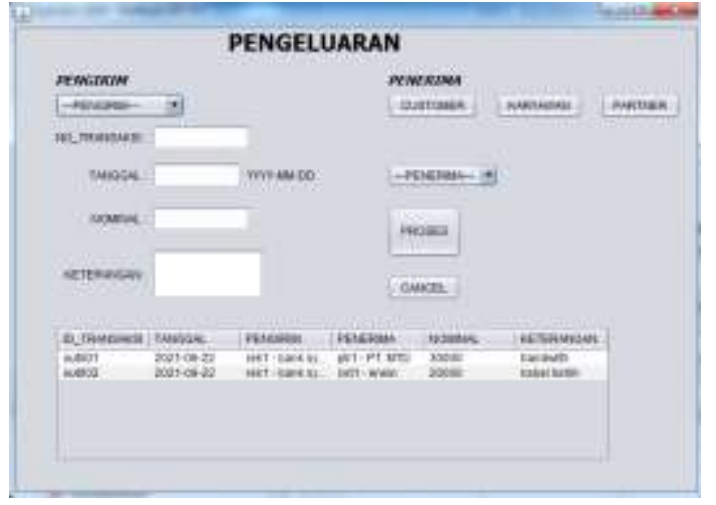

Gambar 14. Form Pengeluaran

Form ini memiliki beberapa fungsi tombol yang terdiri dari pilihan tombol penerima yang terdiri dari tombol (karyawan, customer, partner) yang berfungsi untuk memilih penerima keuangan, lalu terdapat combobox untuk memilih pengirim dan penerima keuangan, tombol proses digunakan untuk menambah data yang telah di-input user, serta tombol cancel digunakan untuk kembali ke menu utama.

\section{SIMPULAN DAN SARAN}

Berdasarkan hasil penelitian aplikasi pengolahan data keuangan berbasis Java pada CV. ADM Technology menggunakan NetBeans dengan tujuan mempermudah pekerjaan user dalam mengolah data keuangan dapat diperoleh kesimpulan yaitu laporan keuangan yang sudah terintegrasi dengan sistem informasi yang lebih akurat dan efisien sehingga dapat mengurangi kecurangan penggunaan dana. Proses pencatatan data mulai dari perhitungan manual pemasukan dan pengeluaran sampai tahap pencatatan laporan keuangan sudah berjalan lebih baik dan dapat mengendalikan serta mengolah keuangan. Mempercepat pencarian data keuangan sehingga dapat lebih efisien dalam menggunakan waktu dan biaya serta dapat membantu dalam pembuatan laporan keuangan. Mempermudah mendapatkan informasi dana yang sudah digunakan sehingga dapat meminimalisasi penggunaan dana yang berlebihan.

Penulis menyadari bahwa masih terdapat kekurangan dalam sistem ini,untuk itu melalui bagian ini penulis hendak memberikan saran bagi pengembangan dan penyempurnaan sistem ini diantaranya dengan menambahkan hak akses untuk bagian karyawan sehingga bisa melakukan request penggunaan 
keuangan. Dan untuk kesempurnaan program ini, lebih baik ada perkembangan lanjutan.

\section{UCAPAN TERIMAKASIH}

Dalam penyusunan artikel ini penulis ingin mengucapkan terimakasih kepada pihakpihak yang telah mendukung saya dalam menyelesaikan artikel ini, maka penulis dalam kesempatan ini dengan hati yang tulus penulis mengucapkan terima kasih pada Allah SWT yang memberi kenikmatan berupa sehat bagi penulis dalam menyelesaikan artikel ini. Kedua orang tua yang selama ini telah membantu untuk memberi semangat, dan doa untuk menyelesaikan artikel ini. Panitia pelaksanaan Seminar Nasional Riset dan Teknologi (SEMNAS RISTEK) yang telah me-review untuk menyelesaikan artikel ini.

\section{DAFTAR PUSTAKA}

Adi, S., \& Kristin, D. M. (2014). Strukturisasi Entity Relationship Diagram dan Data Flow Diagram Berbasis Business EventDriven. Binus University.

Ajid, S. N., \& Rismayadi, A. A. (2021). Aplikasi Pendaftaran Online Pada Klub Bola Voli Bahana Bina Pakuan Kota Bandung Berbasis Website. Universitas Adhirajasa Reswara Sanjaya.

Darmansyah, M. A. (2014). Pengertian Pemrograman JAVA. https://marifdarmansyah.wordpress.com /materi-informatika/pengertianpemrograman-java/

Dosen Pendidikan. (2014). 13 Pengertian Aplikasi Menurut Para Ahli. https://www.dosenpendidikan.co.id/pen gertian-aplikasi-menurut-para-ahli/

Fitriani, B., Angraini, T., \& Putra, Y. H. G. (2018). Pemodelan Use Case Diagram Sistem Informasi Inventaris Laboratorium Teknik Mesin. STMIK Pontianak.

Pelayanan Publik. (2020). Arti Pengolahan Data, Cara Kerja, Fungsi Hingga Contohnya.

https://pelayananpublik.id/2020/04/06/a rti-pengolahan-data-cara-kerja-fungsihingga-contohnya/

Rynny, N. A. (2019). Pengertian Keuangan Menurut Para Ahli. http://hisyam38.blogspot.com/2019/02/ pengertian-keuangan-menurut-paraahli.html

Santosa, P. (2015). Metode Penelitian Sastra.
Azzagrafika Yogyakarta.

Sianipar, R. H. (2015). Membangun Web Dengan PHP Dan MySQL. Bandung Informatika.

Zahra, A. N., Rosidana, M., \& Sari, R. (2018). Implementasi Algoritma DDA pada Pemrograman Java Netbeans. STMIK Sumedang. 